\title{
JAPANESE ENCEPHALITIS VIRUS-SPECIFIC PROLIFERATIVE RESPONSES OF HUMAN PERIPHERAL BLOOD T LYMPHOCYTES
}

\author{
EIJI KONISHI, ICHIRO KURANE, PETER W. MASON, \\ BRUCE L. INNIS, AND FRANCIS A. ENNIS \\ Department of Medical Zoology, Kobe University School of Medicine, Kobe, Japan; Division of \\ Infectious Diseases and Immunology, Department of Medicine, University of Massachusetts Medical \\ Center, Worcester, Massachusetts; Plum Island Animal Disease Center, Agricultural Research \\ Service, United States Department of Agriculture, Greenport, New York; Department of Virology, \\ Armed Forces Research Institute of Medical Sciences, Bangkok, Thailand
}

\begin{abstract}
The $\mathrm{T}$ lymphocytes play an important role in prevention and recovery from viral infections. To characterize $T$ lymphocyte responses to Japanese encephalitis (JE) virus infections, we analyzed JE virus-specific $T$ lymphocytes in peripheral blood mononuclear cells (PBMC) obtained from seven JE patients and 10 vaccinees who had received a formalin-inactivated, purified $\mathrm{JE}$ virus vaccine (Biken vaccine). These PBMC were examined for proliferative responses against live JE virus, a glutaraldehyde-fixed lysate of cells infected with $\mathrm{JE}$ virus, and extracellular particles (EPs; subviral membrane vesicles released from cells infected with recombinant vaccinia viruses encoding the JE virus premembrane and envelope proteins). Japanese encephalitis virus-specific $\mathrm{T}$ cell proliferation was demonstrated with PBMC from both patients and vaccinees after stimulation with infectious JE virus or the lysate of JE virus-infected cells. Proliferating PBMC included CD4 ${ }^{+} \mathrm{T}$ lymphocytes and $\mathrm{CD} 8{ }^{+} \mathrm{T}$ lymphocytes in responses to either form of JE viral antigens. Responses to EPs were observed only with PBMC from some American vaccinees whose PBMC also responded to the virus and lysate. These results indicate that $\mathrm{JE}$ virus infection and immunization with an inactivated $\mathrm{JE}$ vaccine induce $\mathrm{JE}$ virus-specific $\mathrm{CD}^{+}$and $\mathrm{CD}^{+}{ }^{+} \mathrm{T}$ memory lymphocytes that can be induced to proliferate by infectious JE virus and noninfectious JE antigens.
\end{abstract}

Japanese encephalitis (JE) virus is a member of the Flaviviridae and causes human central nervous system disease. Infections with JE virus are a significant cause of mortality and morbidity in many areas of the world, especially in Southeast Asia. Clinically overt JE infection causes fever, headache, and impaired consciousness that results in death in $5-20 \%$ of patients and in permanent neurologic impairment for many survivors. ${ }^{1.2}$ Infection with JE virus stimulates a strong humoral immune response: the detection of immunoglobulin $\mathrm{M}$ (IgM) to JE virus or a significant increase in the titer of total antibody to $\mathrm{JE}$ virus is the laboratory criterion most often used for diagnosis of infection. Although humoral immunity to $\mathrm{JE}$ virus has been extensively studied in humans, cellular immunity has not.

Cellular immunity against infection with flaviviruses has been studied using dengue..$^{3-9}$ Murray Valley encephalitis, ${ }^{7.10}$ Kunjin, ${ }^{11-13}$ and West Nile viruses. ${ }^{6.13}$ Reports on JE virus using a mouse model revealed the presence of $T$ suppressor cells, ${ }^{14-16} \mathrm{~T}$ helper cells, ${ }^{6}$ and $\mathrm{B}$ memory lymphocytes. ${ }^{17}$ However, there have been no reports of human $\mathrm{T}$ lymphocyte responses to $\mathrm{JE}$ vaccination or infection.

Currently, the only JE vaccine approved for humans is a formalin-inactivated virion preparation purified from $\mathrm{JE}$ virus-infected mouse brains. ${ }^{18}$ Although this inactivated vaccine has been demonstrated to be safe and effective, ${ }^{19}$ it is expensive and has been occasionally associated with serious adverse reactions. ${ }^{20}$ Recombinant poxviruses encoding the premembrane (prM) and envelope (E) genes of JE virus have been developed as a candidate second generation $\mathrm{JE}$ vaccine to address the limitations of existing products. ${ }^{21-24}$ The recombinant poxviruses elicited high levels of protective antibodies to JE virus in mice. The antibody responses of these recombinant poxviruses correlated with their ability to induce the synthesis of extracellular particles (EPs) in tissue culture cells. Furthermore, these EPs, which are virus-like membrane vesicles containing prM, membrane (M), and $\mathrm{E}$ proteins, are immunogenic and protective in mice, ${ }^{24.25}$ and could be considered for use as a subunit vaccine. To increase their safety, our second generation JE vaccine candidates were based on a highly attenuated vaccinia virus $\operatorname{strain}^{23}$ or a canarypox strain. ${ }^{24}$

Effective evaluation of these vaccine candidates in humans will require information on human $T$ cell responses against JE virus. In this paper we analyze JE virus-specific $T$ lymphocytes in peripheral blood mononuclear cells (PBMC) from patients recovering from JE and vaccinees who had received the commercially available inactivated vaccine. The PBMC from the JE-immune donors proliferated in vitro after stimulation with $\mathrm{JE}$ viral antigens, and the proliferating cells included $\mathrm{CD}^{+}$and $\mathrm{CD}^{+}{ }^{+} \mathrm{T}$ lymphocytes. The $T$ cells from some vaccinees also responded to the EPs that contained prM/M and $\mathrm{E}$ proteins. This report presents the first information on JE virus-specific human $T$ lymphocytes.

\section{MATERIALS AND METHODS}

Human PBMC. The peripheral blood specimens were obtained from three different groups. The first group consisted of seven adult American vaccinees (designated VU1 to VU7) who had been immunized three or more times with the formalin-inactivated JE vaccine (Biken vaccine) ${ }^{18}$ within the past five years prior to the time of the study and who resided in the United States, where JE virus is absent. The second group consisted of three adult Japanese vaccinees (designated $\mathrm{VJ} 1$ to $\mathrm{VJ} 3$ ) who had been vaccinated during their childhood, had been given booster vaccinations within the previous five years, and had resided in no other area endemic for JE except Japan. One Japanese vaccinee (VJ1) provided two specimens: the first (VJ1-1) was a baseline sample, and the second (VJ1-2) was collected one week after a booster vaccination. The third group consisted of seven 
Thai patients (designated PT1 to PT7) who survived an episode of JE defined by the presence of fever, impaired consciousness, and detection of IgM antibodies to JE virus in the acute cerebrospinal fluid. ${ }^{26,27}$ Their blood samples were collected from one to seven months after the onset of the disease. The control PBMC specimens were collected from two cord blood samples (designated CB1 and CB2) supplied by the University of Massachusetts Medical Center. The PBMC were separated by Ficoll-Hypaque density gradient centrifugation as previously described, ${ }^{4}$ resuspended at a concentration of $1 \times 10^{7} / \mathrm{ml}$ in RPMI 1640 medium containing $10 \%$ fetal bovine serum and $10 \%$ dimethylsulfoxide, and cryopreserved in liquid nitrogen until use.

Viruses. The Nakayama strain of JE virus ${ }^{28}$ was prepared in an Aedes albopictus cell line (C6/36), ${ }^{29}$ which was obtained from the American Type Culture Collection (Rockville, $M D)$. A recombinant vaccinia virus encoding the prM and $E$ genes of the Nakayama strain of JE virus, vP829, ${ }^{22}$ and its parent virus, $\mathrm{vP} 410,{ }^{21}$ have been previously described.

Viral antigens. Live virus, fixed lysate of cells infected with $\mathrm{JE}$ virus and purified EPs were used as viral antigens in PBMC proliferation assays. Culture fluid of C6/36 cells infected with $\mathrm{JE}$ virus at a multiplicity of infection (MOI) of five and incubated at $28^{\circ} \mathrm{C}$ for $48 \mathrm{hr}$ was used as the live virus antigen (virus titer of approximately $2 \times 10^{8}$ plaqueforming units $/ \mathrm{ml}$ ). The fixed cell lysate was prepared from cells infected with $\mathrm{JE}$ virus essentially as described. ${ }^{4}$ Briefly, Vero cells were infected with JE virus at an MOI of five, incubated at $37^{\circ} \mathrm{C}$ for $24 \mathrm{hr}$, fixed in $0.025 \%$ glutaraldehyde, sonicated, and clarified. The EPs were purified from culture fluid of HeLa cells infected with vP829 as described. ${ }^{25}$ The amounts of the JE virus $\mathrm{E}$ protein contained in the fixed cell lysate and the EP antigens were $4 \mu \mathrm{g} / \mathrm{ml}$ and $30 \mu \mathrm{g} / \mathrm{ml}$, respectively, as estimated by Coomassie blue and immunochemical staining. Control antigens for the live virus and infected cell lysate consisted of uninfected C6/36 cell culture fluid and uninfected Vero cell lysate. Control preparations for the EP antigen were prepared from the culture fluid of cells infected with vP410 by the same procedure used to purify the EPs.

Radioimmunoprecipitation (RIP). Serum or plasma specimens obtained from PBMC donors were tested for their ability to immunoprecipitate ${ }^{35} \mathrm{~S}$-labeled viral proteins harvested from the lysate of JE virus-infected cells as previously described. ${ }^{21}$

Proliferation assay of PBMC. Proliferative responses of PBMC were measured as previously described. ${ }^{4}$ The PBMC $\left(2 \times 10^{5}\right)$ were cultured with different dilutions of each of the viral and control antigens in $0.2 \mathrm{ml}$ of AIM V medium (GIBCO BRL, Gaithersburg, MD) containing 10\% human AB serum (Hazleton Research Products, Inc., Lenexa, KS) in 96-well V-bottom microplates (Costar, Cambridge, MA) at $37^{\circ} \mathrm{C}$. Based on the results of previous experiments, the cell lysate was used at 1:20,1:100, and 1:500 dilutions, live virus was used at 1:4, 1:8, and 1:16 dilutions, and EP was used at 1:10, 1:50, and 1:250 dilutions. Six days after addition of antigen, cells were pulsed with $1 \mu \mathrm{Ci}$ of tritiated $\left.{ }^{3} \mathrm{H}\right)$ thymidine for $18 \mathrm{hr}$ before being harvested using a multiharvester (Titertek, Skatron Inc., Sterling, VA), and ${ }^{3} \mathrm{H}$ thymidine incorporation was determined by liquid scintilla- tion counting (1205 Betaplate; Pharmacia, Wallac Oy, Finland). To improve the specific proliferative responses of PBMC, T cell growth factor (TCGF; T-stim Culture Supplement; Collaborative Biomedical Products, Bedford, MA) was added to the PBMC from Thai patients, which had a lower degree of viability at a final concentration of $1 \%$ or $10 \%$ six days after antigen addition except for those of PT2. Stimulation indices were calculated by the standard formula: count per minute (cpm) induced by JE antigen divided by cpm induced by control antigen at the same dilution. The criteria to determine positive responses were 1) a stimulation index equal to or greater than 2.7 and 2) a total cpm obtained with viral antigens greater than 500. A stimulation index equal to or greater than 2.7 was considered as a positive proliferation response, since the maximum value of the stimulation index of cord blood lymphocytes (for each concentration of antigens) plus 1.96 times the standard error of the mean was 2.68.

Phenotypic analysis. The $\mathrm{T}$ lymphocyte depletion test was performed using anti-CD4 and anti-CD8 monoclonal antibodies (OKT4 and OKT8; Ortho Diagnostic Systems, Inc., Raritan, $\mathrm{NJ}$ ) as described. ${ }^{9}$ Briefly, approximately $1 \times$ $10^{6}$ PBMC stimulated with the lysate at a 1:20 dilution or the virus at a 1:4 dilution were incubated with antibody at a $1: 11$ dilution at $4^{\circ} \mathrm{C}$ for $30 \mathrm{~min}$, treated with rabbit complement (Cedarlane Laboratories, Hornby, Ontario, Canada) at a 1:5 dilution at $37^{\circ} \mathrm{C}$ for $1 \mathrm{hr}$, and then used in proliferation assays. The incorporation of ${ }^{3} \mathrm{H}$-thymidine was compared with that obtained with cells treated with mouse IgG and complement. The percentage of the cells surviving after depletion treatment (as shown by staining with the monoclonal antibody used for depletion) had been demonstrated to be less than $3 \%$ in previous experiments.

\section{RESULTS}

Antibody status. Figure 1 shows the RIP results of serum or plasma specimens obtained from patients and vaccinees. All the patients showed strong reactions to the $E$ protein of $\mathrm{JE}$ virus, and eight of 10 vaccinees had detectable antibody against the $E$ protein. The specific reaction of one Japanese vaccinee (VJ1-1) against $E$ protein was not detectable on this autoradiograph, but the specimen taken from the same individual one week after vaccination (VJ1-2) showed a faint band, as did VU4. The specimens from VU2 and VJ2 did not show any detectable reactions against the $\mathrm{E}$ protein.

Patients had antibodies against nonstructural protein 1 (NS1) and NS3 of JE virus, but American vaccinees did not have antibodies against these nonstructural proteins. This difference was anticipated since nonstructural proteins of $\mathrm{JE}$ virus are excluded from the vaccine during its purification. One of three Japanese vaccinees (VJ3) had low levels of anti-NS1 and anti-NS3 antibodies that were only visible with longer exposure of the gel used to produce the autoradiographs shown in Figure 1.

Proliferative responses of PBMC. The results of the proliferation assays of PBMC obtained from seven American vaccinees and two cord blood samples are shown in Table 1. Positive responses against viral antigens were observed in three vaccinees (VU1, VU3, and VU6), and the PBMC of these three donors responded to all three antigen prepara- 


\begin{tabular}{|c|c|c|c|c|c|c|c|c|c|c|c|c|c|c|c|c|c|}
\hline \multicolumn{7}{|c|}{$\begin{array}{c}\text { American } \\
\text { Vaccinees }\end{array}$} & \multicolumn{4}{|c|}{$\begin{array}{l}\text { Japanese } \\
\text { Vaccinees }\end{array}$} & \multicolumn{7}{|c|}{$\begin{array}{c}\text { Thai } \\
\text { Patients }\end{array}$} \\
\hline VU & $\begin{array}{c}\text { VU } \\
2\end{array}$ & \begin{tabular}{|c|} 
VU \\
3
\end{tabular} & $\begin{array}{c}\mathrm{VU} \\
4\end{array}$ & $\begin{array}{c}\text { VU } \\
5\end{array}$ & $\begin{array}{c}\mathrm{VU} \\
6\end{array}$ & ${ }_{7}^{\text {VU }}$ & \begin{tabular}{|l|}
$V J$ \\
$1-1$ \\
\end{tabular} & \begin{tabular}{|c|}
$\mathbf{V J}$ \\
$1-2$
\end{tabular} & \begin{tabular}{|c|}
$\mathbf{V J}$ \\
2
\end{tabular} & \begin{tabular}{|c|}
$\mathbf{V J}$ \\
$\mathbf{3}$
\end{tabular} & $\begin{array}{c}\text { PT } \\
1\end{array}$ & $\begin{array}{c}\text { PT } \\
2\end{array}$ & $\begin{array}{c}\mathbf{P T} \\
\mathbf{3}\end{array}$ & $\begin{array}{c}\text { PT } \\
4\end{array}$ & $\begin{array}{c}\text { PT } \\
5\end{array}$ & $\begin{array}{c}\text { PT } \\
6\end{array}$ & \begin{tabular}{|l} 
PT \\
7
\end{tabular} \\
\hline
\end{tabular}

NS3 -

NS1':

NS1 -

FIGURE 1. Japanese encephalitis (JE) virus-specific reactivity of sera or plasma obtained from American vaccinees (VU1 to VU7), Japanese vaccinees (VJ1-1 to VJ3), and Thai patients (PT1 to PT7). These specimens were tested for their ability to immunoprecipitate radiolabeled proteins harvested from JE virus-infected cells. The positions of $\mathrm{JE}$ virus proteins are shown on the left side of the autoradiograph. $\mathrm{E}=$ envelope protein; NS1 and NS3 = nonstructural proteins; NS1' = a higher molecular weight form of NS1 produced by alternative processing of the sequences encoded by the NS2A region of the JE virus genome. ${ }^{30}$

tions: JE virus-infected cell lysate, live virus, and EP. The antigen dose that provided the maximum stimulation index varied in different donors. Proliferation assays of PBMC from three Japanese vaccinees showed that PBMC of two donors (VJ1-2 and VJ3) responded to the lysate and PBMC of the donor VJ3 also responded to the virus (Table 2); however, none of these three Japanese vaccinees showed responses to EP.

Proliferative responses of PBMC from Thai JE patients are shown in Table 3. Since recovery of these PBMC samples from cryopreservation was lower than with other PBMC samples, TCGF was added to the PBMC culture at a final concentration of $10 \%$ or $1 \%$ on day 6 to amplify the response in all assays except for those of PT2. Six of seven patients showed responses to the lysate antigens, and five patients showed responses to the live virus. The PBMC of four patients (PT1, PT2, PT3, and PT5) also responded to the lysate and JE virus without addition of TCGF. No patients showed responses against the EP.

Phenotypic analysis of cells responding to antigens. To characterize the proliferating cells, we depleted specific $T$ lymphocyte populations from the PBMC using monoclonal antibodies and complement before ${ }^{3} \mathrm{H}$-thymidine incorporation (Table 4). Cell depletion tests indicate that $\mathrm{T}$ lympho-

TABLE 1

Proliferative responses of peripheral blood mononuclear cells from seven American vaccinees (VH) and two cord blood (CB) samples*

\begin{tabular}{|c|c|c|c|c|c|c|c|c|c|c|}
\hline \multirow[b]{2}{*}{ Antigen } & \multirow[b]{2}{*}{ Dilution } & \multicolumn{9}{|c|}{ Stimulation index after stimulation with antigens } \\
\hline & & vU1 & VU2 & vU3 & VU4 & vU5 & vU6 & vU7 & CBI & CB2 \\
\hline Lysate & $\begin{array}{l}1: 20 \\
1: 100 \\
1: 500\end{array}$ & $\begin{array}{c}3.9 \\
(2,274) \\
9.9 \\
(5,710) \\
4.5 \\
(3,141)\end{array}$ & $\begin{array}{l}1.0 \\
(456) \\
1.8 \\
(528) \\
0.9 \\
(246)\end{array}$ & $\begin{array}{l}1.4 \\
(369) \\
2.5 \\
(701) \\
2.7 \\
(1,038)\end{array}$ & $\begin{array}{l}1.4 \\
(803) \\
2.2 \\
(834) \\
0.7 \\
(406)\end{array}$ & $\begin{array}{c}1.2 \\
(168) \\
1.2 \\
(116) \\
1.0 \\
(95)\end{array}$ & $\begin{array}{c}1.3 \\
(187) \\
9.9 \\
(1,921) \\
16.2 \\
(2,323)\end{array}$ & $\begin{array}{l}1.7 \\
(1,060) \\
1.7 \\
(815) \\
1.8 \\
(1,436)\end{array}$ & $\begin{array}{c}0.9 \\
(1,464) \\
2.2 \\
(1,689) \\
0.7 \\
(737)\end{array}$ & $\begin{array}{c}0.9 \\
(1,493) \\
2.0 \\
(2,853) \\
0.7 \\
(1,273)\end{array}$ \\
\hline Virus & $\begin{array}{l}1: 4 \\
1: 8 \\
1: 16\end{array}$ & $\begin{array}{c}2.3 \\
(18,631) \\
3.8 \\
(16,578) \\
0.8 \\
(5,105)\end{array}$ & $\begin{array}{c}0.9 \\
(3,380) \\
0.9 \\
(1,283) \\
0.9 \\
(624)\end{array}$ & $\begin{array}{c}3.1 \\
(9,287) \\
1.8 \\
(7,098) \\
4.3 \\
(5,669)\end{array}$ & $\begin{array}{c}1.3 \\
(6,130) \\
1.3 \\
(3,098) \\
0.7 \\
(1,877)\end{array}$ & $\begin{array}{c}1.6 \\
(364) \\
0.5 \\
(123) \\
1.0 \\
(89)\end{array}$ & $\begin{array}{c}15.0 \\
(8,070) \\
5.3 \\
(4,457) \\
3.5 \\
(1,645)\end{array}$ & $\begin{array}{c}1.5 \\
(10,598) \\
1.1 \\
(5,661) \\
1.9 \\
(6,597)\end{array}$ & $\begin{array}{c}1.5 \\
(10,919) \\
1.3 \\
(5,410) \\
0.8 \\
(3,799)\end{array}$ & $\begin{array}{c}0.8 \\
(7,532) \\
0.7 \\
(5,637) \\
0.6 \\
(2,346)\end{array}$ \\
\hline EP & $\begin{array}{l}1: 10 \\
1: 50 \\
1: 250\end{array}$ & $\begin{array}{c}3.2 \\
(12,237) \\
1.4 \\
(12,890) \\
2.3 \\
(9,813)\end{array}$ & $\begin{array}{l}0.4 \\
(156) \\
0.4 \\
(255) \\
0.6 \\
(253)\end{array}$ & $\begin{array}{c}2.2 \\
(600) \\
4.9 \\
(1,908) \\
2.9 \\
(1,138)\end{array}$ & $\begin{array}{l}1.1 \\
(301) \\
0.6 \\
(462) \\
0.7 \\
(316)\end{array}$ & $\begin{array}{l}0.2 \\
(84) \\
1.1 \\
(114) \\
0.8 \\
(82)\end{array}$ & $\begin{array}{c}11.5 \\
(2,328) \\
3.8 \\
(721) \\
5.4 \\
(954)\end{array}$ & $\begin{array}{l}0.7 \\
(454) \\
1.4 \\
(952) \\
0.9 \\
(982)\end{array}$ & $\begin{array}{l}0.8 \\
(469) \\
1.6 \\
(1,306) \\
0.8 \\
(709)\end{array}$ & $\begin{array}{c}0.8 \\
(423) \\
1.3 \\
(1,787) \\
1.1 \\
(1,731)\end{array}$ \\
\hline
\end{tabular}

* Underlined values indicate significant levels of proliferation. Values in parentheses are counts per minute. The data represent the averages of three wells. EP $=$ extracellular particle. 
TABLE 2

Proliferative responses of peripheral blood mononuclear cells from three Japanese vaccinees*

\begin{tabular}{lccccc}
\hline & & \multicolumn{4}{c}{ Stimulation index } \\
\cline { 3 - 6 } Antigen & Dilution & VJ1-1 & VJ1-2 & VJ2 & VJ3 \\
\hline Lysate & $1: 20$ & 0.6 & 0.4 & 0.9 & 3.7 \\
& & $(175)$ & $(1,548)$ & $(1,652)$ & $(3,960)$ \\
& $1: 100$ & 0.9 & 2.8 & 1.3 & 2.2 \\
& & $(135)$ & $(8,241)$ & $(1,441)$ & $(2,190)$ \\
& $1: 500$ & 1.1 & 1.8 & 1.1 & 1.4 \\
Virus & & $(149)$ & $(6,902)$ & $(985)$ & $(724)$ \\
& $1: 4$ & 0.3 & 1.8 & 1.1 & 1.7 \\
& $1: 8$ & $(219)$ & $(24,533)$ & $(6,586)$ & $(8,399)$ \\
& & 0.9 & 0.6 & 0.7 & 1.9 \\
& $1: 16$ & $(145)$ & $(8,908)$ & $(3,908)$ & $(4,275)$ \\
& & 1.0 & 1.1 & 0.4 & 3.2 \\
& & $(135)$ & $(7,119)$ & $(1,460)$ & $(3,965)$ \\
\hline
\end{tabular}

* Underlined values indicate significant levels of proliferation. Values in parentheses are counts per minute. The data represent the averages of three wells. One individual (VJ1) provided two specimens.

cyte populations in PBMC that proliferated in responses to the lysate and live virus included both $\mathrm{CD}^{+} \mathrm{T}$ lymphocytes and $\mathrm{CDB}^{+} \mathrm{T}$ lymphocytes in patients and vaccinees. The percent decrease in stimulation by lysate after treatment with anti-CD4 and complement was almost twice as great as that after treatment with anti-CD8 and complement, indicating that $\mathrm{JE}$ virus-specific $\mathrm{CD}^{+}{ }^{+}$lymphocytes were more prevalent (Table 4). The relative percent decreases achieved by treatments with anti-CD4 or anti-CD8 and complement were similar after stimulation with JE virus (Table 4).

\section{DISCUSSION}

This report describes the detection in vaccinees and recovered patients of antibodies to both structural and nonstructural proteins of JE virus and JE virus-specific T memory lymphocytes. The results are summarized in Table 5. Our preliminary characterization of $\mathrm{T}$ lymphocyte proliferative responses establishes another outcome measure with which to evaluate the possible effectiveness of a candidate second generation vaccine. The $92 \%$ efficacy of the first gen-
TABLE 4

Effect of monoclonal antibodies and complement on the proliferation of peripheral blood mononuclear cells responding to Japanese encephalitis viral antigens*

\begin{tabular}{|c|c|c|c|c|}
\hline \multirow[b]{3}{*}{ Antigen } & \multirow[b]{3}{*}{ Donor } & \multicolumn{3}{|c|}{${ }^{3} \mathrm{H}$-thymidine incorporation (counts per minute) } \\
\hline & & \multicolumn{2}{|c|}{$\begin{array}{l}\text { Treated with complement and } \\
\text { monoclonal antibody to }\end{array}$} & \multirow[b]{2}{*}{ Control IgG } \\
\hline & & CD4 & CD8 & \\
\hline \multirow[t]{2}{*}{ Lysate $†$} & PT5 & $3,618(50.8 \%)$ & $5,324(27.5 \%)$ & 7,348 \\
\hline & VJ3 & $3,882(44.7 \%)$ & $5,548(21.0 \%)$ & 7,019 \\
\hline Virus $\ddagger$ & VJ3 & $1,349(63.8 \%)$ & $2,044(45.2 \%)$ & 3,730 \\
\hline
\end{tabular}

eration vaccine was demonstrated in a field trial in Thailand; 19 therefore, a placebo-controlled trial of any new JE vaccine would be unethical. Evidence of vaccine efficacy will be based on protection studies in animals and on surrogate responses of volunteers to vaccination. The ability of vaccine to elicit neutralizing antibody is one candidate surrogate marker. The ability of vaccine to elicit $T$ cell responses is also proposed as a new candidate marker. Specifically, $T$ cell proliferation responses would be advantageous to evaluate recipients of live recombinant vaccine candidates, since in general, cytotoxic $T$ lymphocytes can be induced by infection with live viruses in contrast to immunization with proteins or peptides; therefore, $\mathrm{T}$ lymphocyte proliferative responsiveness does not always correlate with antibody.

The presence of antibodies to nonstructural proteins of JE virus distinguished individuals infected with $\mathrm{JE}$ virus from those immunized with an inactivated whole virion vaccine. All seven patients recovering from the disease had antibodies to NS1 and NS3: in contrast, none of seven American vaccinees had those antibodies. These findings indicate that during infection with JE virus, the immune system, including $T$ lymphocytes, encounters both structural and nonstructural virus protein antigens, but that during vaccination with inactivated vaccine, $\mathrm{T}$ lymphocytes encounter only structural virus protein antigens. Therefore, it is likely that the single Japanese vaccinee (VJ3) who had anti-NS1 and anti-NS3

TABLE 3

Proliferative responses of peripheral blood mononuclear cells (PBMC) from seven Thai patients with Japanese encephalitis*

\begin{tabular}{|c|c|c|c|c|c|c|c|c|}
\hline \multirow[b]{2}{*}{ Antigen } & \multirow[b]{2}{*}{ \% TCGF } & \multicolumn{7}{|c|}{ Stimulation index after stimulation with antigens } \\
\hline & & PTI & PT2 & PT3 & PT4 & PT5 & PT6 & PT7 \\
\hline Lysate $†$ & $\begin{array}{l}1 \\
0\end{array}$ & $\begin{array}{c}3.5 \\
(14,262) \\
4.6 \\
(7,367) \\
7.1 \\
(9,687)\end{array}$ & $\begin{array}{c}9.2 \\
(2,252) \\
5.4 \\
(1,009) \\
3.0 \\
(533)\end{array}$ & $\begin{array}{c}12.0 \\
(35,460) \\
12.1 \\
(31,654) \\
9.5 \\
(19,885)\end{array}$ & $\begin{array}{c}5.0 \\
(2,139) \\
1.4 \\
(564) \\
1.3 \\
(602)\end{array}$ & $\begin{array}{c}6.7 \\
(29,650) \\
2.3 \\
(13,348) \\
3.0 \\
(10,291)\end{array}$ & $\begin{array}{c}2.1 \\
(3,632) \\
3.5 \\
(5,072) \\
0.7 \\
(1,126)\end{array}$ & $\begin{array}{c}1.9 \\
(4,564) \\
1.2 \\
(2,794) \\
1.1 \\
(1,558)\end{array}$ \\
\hline Virus $\ddagger$ & $\begin{array}{r}10 \\
1\end{array}$ & $\begin{array}{c}4.4 \\
(3,301) \\
7.5 \\
(3,972) \\
4.0 \\
(3,479)\end{array}$ & $\begin{array}{c}4.0 \\
(2,291) \\
2.4 \\
(1,455) \\
3.3 \\
(738)\end{array}$ & $\begin{array}{c}4.1 \\
(25,733) \\
4.1 \\
(26,800) \\
6.0 \\
(14,476)\end{array}$ & $\begin{array}{l}1.0 \\
(1,119) \\
0.8 \\
(203) \\
1.0 \\
(156)\end{array}$ & $\begin{array}{c}4.0 \\
(27,501) \\
2.1 \\
(6,772) \\
4.0 \\
(4,860)\end{array}$ & $\begin{array}{c}0.9 \\
(10,125) \\
4.2 \\
(9,878) \\
0.8 \\
(1,245)\end{array}$ & $\begin{array}{c}0.7 \\
(903) \\
0.5 \\
(1,937) \\
0.5 \\
(249)\end{array}$ \\
\hline
\end{tabular}

* Underlined values indicate significant levels of proliferation. Values in parentheses are counts per minute. The data represent the averages of three wells. T cell growth factor (TCGF) was not used for assay of PBMC from PT2. Data indicate responses against the lysate at dilutions of 1:20 (top line), 1:100 (middle line), and 1:500 (bottom line) and responses against virus at dilutions of 1:4 (top line), 1:8 (middle line), and 1:16 (bottom line).

$\uparrow 1: 20$ dilution except for PT2.

$\$$ 1:16 dilution except for PT2. 
TABLE 5

Summary of proliferative responses against Japanese encephalitis virus antigens*

\begin{tabular}{|c|c|c|c|c|c|}
\hline \multirow[b]{2}{*}{ Donor } & \multicolumn{2}{|c|}{ Antibody to } & \multicolumn{3}{|c|}{ T cell response to } \\
\hline & $\underset{\text { protein }}{E}$ & $\begin{array}{c}\text { NSI/NS3 } \\
\text { proteins }\end{array}$ & Lysate & Virus & EP \\
\hline \multicolumn{6}{|c|}{ American vaccinees } \\
\hline VU1 & + & - & + & + & + \\
\hline VU2 & - & - & - & - & - \\
\hline VU3 & + & - & + & + & + \\
\hline VU4 & + & - & - & - & - \\
\hline VU5 & + & - & - & - & - \\
\hline VU6 & + & - & + & + & + \\
\hline VU7 & + & - & - & - & - \\
\hline \multicolumn{6}{|c|}{ Japanese vaccinees } \\
\hline VJ1 & + & - & + & - & - \\
\hline VJ2 & - & - & - & - & - \\
\hline VJ3 & + & + & + & + & - \\
\hline \multicolumn{6}{|l|}{ Patients } \\
\hline PT1 & + & + & $+(+)$ & $+(+)$ & - \\
\hline PT2 & + & + & + & + & - \\
\hline PT3 & + & + & $+(+)$ & $+(+)$ & - \\
\hline PT4 & + & + & $-(+)$ & $-(-)$ & - \\
\hline PT5 & + & + & $+(+)$ & $+(+)$ & - \\
\hline PT6 & + & + & $-(+)$ & $-(+)$ & - \\
\hline PT7 & + & + & $-(-)$ & $-(-)$ & - \\
\hline
\end{tabular}

* $\mathrm{E}=$ envelope; $\mathrm{NS}=$ nonstructural: $\mathrm{EP}=$ extracellular particle: $+=$ positive response - = negative response. Results in parentheses were obtained in the presence of $T$ cell growth factor.

antibodies was naturally and asymptomatically infected with $\mathrm{JE}$ virus in an endemic area (Japan). The presence of antibodies to nonstructural proteins in a vaccinee with detectable levels of neutralizing antibody is consistent with our previous experiments in mice, which showed that animals with high titers of neutralizing antibody that were protected against lethal challenge produced antibodies to nonstructural proteins. $^{22}$

Japanese encephalitis virus-specific $\mathrm{T}$ lymphocytes were detected in donors infected with JE virus or immunized with the inactivated JE vaccine. The presence of specific lymphocytes was shown in proliferation assays using several different antigens. It is of interest that the responses of PBMC against EPs were observed with specimens from American vaccinees but not with specimens from donors who were infected with JE virus and have antibody to nonstructural proteins. Similarly, a Japanese vaccinee who had antibodies against nonstructural protein (VJ3) did not respond to EPs (Table 5). The immunogens encountered by the vaccinees were limited to the structural proteins of JE virus, while those encountered by patients would have included both structural and nonstructural proteins produced in vivo during virus replication. Detection of $\mathrm{T}$ memory cells that respond to structural protein in PBMC of the vaccinees is consistent with immunization with noninfectious JE virus particles. We also expected to find $T$ memory lymphocytes specific for the structural proteins of JE virus in PBMC of the patients, since the structural proteins induced a strong antibody response in these individuals. However, we did not detect any proliferation of $\mathrm{T}$ lymphocytes in PBMC of JE patients after in vitro stimulation with EPs. These results suggest that JE virusspecific $T$ cells in $\mathrm{JE}$ patients respond mainly to nonstructural proteins or capsid (C) protein, and the levels of $\mathrm{T}$ mem- ory cells that respond to $\mathrm{E}$ and $\mathrm{prM} / \mathrm{M}$ proteins are undetectably low. On the other hand, the results may be secondary to the concentration of EPs used as the stimulating antigens.

It is important to determine which proteins of JE virus are recognized by $T$ cells from vaccinees and infected individuals to help ensure induction of $T$ cell immunity in vaccinees, and to help determine differences in $T$ cell responses of patients during $\mathrm{JE}$ infection. Vaccinia expression systems have been used extensively to determine specific viral antigens involved in immune recognition of many viruses, including flaviviruses, in mice. ${ }^{11-13}$ However, our earlier attempts to determine specific antigens of $\mathrm{JE}$ virus in human PBMC using vaccinia-based recombinants ${ }^{22}$ failed because of high responses of human PBMC against vaccinia antigens contained in the cell preparations. However, using the purified EPs, we were able to identify $T$ cells with specific reactivity to $\mathrm{prM} / \mathrm{M}$ and $\mathrm{E}$.

It is generally accepted that in vivo proliferation of human leukocyte antigen (HLA) class I-restricted, $\mathrm{CD}^{+} \mathrm{T}$ lymphocytes tend to be stimulated by antigen presenting cells (APC) infected with live agents and HLA class II-restricted, $\mathrm{CD}^{+} \mathrm{T}$ lymphocytes tend to be stimulated by APC sensitized with noninfectious proteins. We detected the proliferation of both $\mathrm{CD}^{+}$and $\mathrm{CD}^{+}{ }^{+} \mathrm{T}$ cells in PBMC from two donors (PT5 and VJ3). These two donors had antibodies to NS1 and NS3, indicating that they had been infected with $\mathrm{JE}$ virus in the past. The presence of $\mathrm{JE}$ virus-specific CD4+ and $\mathrm{CD8}^{+} \mathrm{T}$ memory cells in PBMC of PT5 and VJ3 is consistent with a history of JE virus infections.

In conclusion, we have demonstrated JE virus-specific proliferation of both $\mathrm{CD}^{+}$and $\mathrm{CD}^{+} \mathrm{T}$ lymphocytes in PBMC from patients and some vaccinees. The PBMC from some vaccinees did not proliferate, which is consistent with low levels of $\mathrm{T}$ memory cells induced by the commercially available inactivated $\mathrm{JE}$ vaccine. It is important to determine the functions of these $\mathrm{CD}^{+}$and $\mathrm{CD} 8{ }^{+} \mathrm{T}$ cells, e.g., cytotoxic functions and lymphokine production, and to define the protein(s) and epitope(s) recognized by these T cells. High levels of proliferation in vitro will make it possible for us to further characterize JE virus-specific T lymphocytes. The improved understanding of JE virus-specific $\mathrm{T}$ lymphocytes may have important implications for the treatment of JE infection and for the development of new vaccines that are safe and effective.

Financial support: This work was supported by grants from the National Institutes of Health (NIH-RO1-AI-30624 and AI-10987-17), the U.S. Army Medical Research and Development Command (DAMD17-90-Z-0020), the National Science Foundation (DMB 8515345), and the Ministry of Education of Japan in aid for Scientific Research (06670328).

Authors' addresses: Eiji Konishi, Department of Medical Zoology, Kobe University School of Medicine, 7-5-1, Kusunoki-cho, Chuoku, Kobe 650, Japan. Ichiro Kurane and Francis A. Ennis, Division of Infectious Diseases and Immunology, Department of Medicine, University of Massachusetts Medical Center, Worcester, MA 01655. Peter W. Mason, Plum Island Animal Disease Center, Agricultural Research Service, United States Department of Agriculture, Greenport, NY 11944. Bruce L. Innis, Department of Viral Diseases, Walter Reed Army Institute of Research, Washington, DC 20307.

Reprint requests: Eiji Konishi, Department of Medical Zoology, 
Kobe University School of Medicine, 7-5-1, Kusunoki-cho, Chuoku, Kobe 650, Japan.

\section{REFERENCES}

1. Shope RE, 1980. Medical significance of togaviruses: an overview of diseases caused by togaviruses in man and in domestic and wild vertebrate animals. Schlesinger RW, ed. The Togaviruses. New York: Academic Press, 47-82.

2. Igarashi A, 1992. Japanese encephalitis: virus, infection, and control. Kurstak E, ed. Control of Virus Diseases. New York: Marcel Dekker, 309-342.

3. Bukowski JF, Kurane I, Lai C-J, Bray M, Falgout B, Ennis FA, 1989. Dengue virus-specific cross-reactive $\mathrm{CD}^{+}{ }^{+}$human cytotoxic T lymphocytes. J Virol 63: 5086-5091.

4. Kurane I, Innis BL, Nisalak A, Hoke C, Nimmannitya S, Meager A, Ennis FA, 1989. Human $T$ cell responses to dengue virus antigens: proliferative responses and interferon gamma production. J Clin Invest 83: 506-513.

5. Kurane I, Meager A, Ennis FA, 1989. Dengue virus-specific human $\mathrm{T}$ cell clones: serotype crossreactive proliferation, interferon $\gamma$ production and cytotoxic activity. J Exp Med 170: 763-775.

6. Kutuhuddin M, Kolaskar AS, Galande S, Gore MM, Ghosh SN, Banerjee K, 1991. Recognition of helper T cell epitopes in envelope (E) glycoprotein of Japanese encephalitis, West Nile and dengue viruses. Mol Immunol 28: 149-154.

7. Roehrig JT, Johnson AJ, Hunt AR, Beaty BJ, Mathews JH, 1992. Enhancement of the antibody response to flavivirus Bcell epitopes by using homologous or heterologous T-cell epitopes. J Virol 66: 3385-3390.

8. Rothman AL, Kurane I, Lai C-J, Bray M, Falgout B, Men R, Ennis FA, 1993. Dengue virus protein recognition by virusspecific murine $\mathrm{CD8}^{+}$cytotoxic $\mathrm{T}$ lymphocytes. $J$ Virol 67 : 801-806.

9. Zivny J, Kurane I, Tacket CO, Edelman R, Ennis FA, 1993. Dengue virus-specific, human $\mathrm{CD}^{+}$cytotoxic $\mathrm{T}$ lymphocytes generated in short-term culture. Viral Immunol 6: 143-151.

10. Mathews JH, Allan JE, Roehrig, JT, Brubaker JR, Uren MF, Hunt AR, 1991. T-helper cell and associated antibody response to synthetic peptides of the E glycoprotein of Murray Valley encephalitis virus. J Virol 65: 5141-5148.

11. Parrish CR, Coia G, Hill A, Mullbacher A, Westaway EG, Blanden RV, 1991. Preliminary analysis of murine cytotoxic $T$ cell responses to the proteins of the flavivirus Kunjin using vaccinia virus expression. J Gen Virol 72: 1645-1653.

12. Kulkarni AB, Mullbacher A, Parrish CR, Westaway EG, Coia G, Blanden RV, 1992. Analysis of murine major histocompatibility complex class II-restricted T-cell responses to the flavivirus Kunjin by using vaccinia virus expression. $J$ Virol 66: 3583-3592.

13. Hill AB, Mullbacher A, Parrish C, Coia G, Westaway EG, Blanden RV, 1992. Broad cross-reactivity with marked fine specificity in the cytotoxic $\mathrm{T}$ cell response to flaviviruses. $J$ Gen Virol 73: 1115-1123

14. Mathur A, Rawat S, Chaturvedi UC, 1983. Induction of suppressor cells in Japanese encephalitis virus infected mice. $\mathrm{Br}$ J Exp Pathol 64: 336-343.
15. Mathur R, Kulshreshtha R, Rawat S, Chaturvedi UC, 1987. Memory suppressor $\mathrm{T}$ cells in latent Japanese encephalitis virus infection. Immunology 60: 71-74.

16. Rawat S, Mathur A, Chaturvedi UC, 1986. Characterization of Japanese encephalitis virus-specific suppressor $T$ cells and their product in suppression of the humoral immune response in mice. Ann Inst Pasteur 137D: 391-401.

17. Kulshreshtha R, Mathur A, Chaturvedi UC, 1988. Immunological memory in latent Japanese encephalitis virus infection. Br J Exp Pathol 69: 465-471.

18. Takaku K, Yamashita T, Osanai T, Yoshida I, Kato M, Goda H, Takagi M, Hirota T, Amano T, Fukai K, Kunita N, Inoue K, Shoji K, Igarashi A, Ito T, 1968. Japanese encephalitis purified vaccine. Biken J 11: 25-39.

19. Hoke CH, Nisalak A, Sangawhipa N, Jatanasen S, Laorakapongse T, Innis BL, Kotchasenee S, Gingrich JB, Latendresse J, Fukai K, Burke DS, 1988. Protection against Japanese encephalitis by inactivated vaccines. $N$ Engl J Med 319: 608614.

20. Andersen MM, Ronne T, 1991. Side-effects with Japanese encephalitis vaccine. Lancet 337: 1044.

21. Mason PW, Pincus S, Fournier MJ, Mason TL, Shope RE, Paoletti E, 1991. Japanese encephalitis virus-vaccinia recombinants produce particulate forms of the structural membrane proteins and induce high levels of protection against lethal JEV infection. Virology 180: 294-305.

22. Konishi E, Pincus S, Fonseca BAL, Shope RE, Paoletti E, Mason PW, 1991. Comparison of protective immunity elicited by recombinant vaccinia viruses that synthesize E or NS1 of Japanese encephalitis virus. Virology 185: 401-410.

23. Konishi E, Pincus S, Paoletti E, Laegreid WW, Shope RE, Mason PW, 1992. A highly attenuated host-range restricted vaccinia virus strain, NYVAC, encoding the prM, E and NS 1 genes of Japanese encephalitis virus prevents JEV viremia in swine. Virology 190: 454-458.

24. Konishi E, Pincus S, Paoletti E, Shope RE, Mason PW, 1994. Avipox virus-vectored Japanese encephalitis virus vaccines: use as vaccine candidates in combination with purified subunit immunogens. Vaccine 12: 633-638.

25. Konishi E, Pincus S, Paoletti E, Shope RE, Burrage T, Mason PW, 1992. Mice immunized with a subviral particle containing the Japanese encephalitis virus $\mathrm{prM} / \mathrm{M}$ and $\mathrm{E}$ proteins are protected from lethal JEV infection. Virology 188: 714-720.

26. Burke DS, Nisalak A, Ussery MA, 1982. Antibody capture immunoassay detection of Japanese encephalitis virus immunoglobulin $\mathbf{M}$ and $\mathbf{G}$ antibodies in cerebrospinal fluid. $J$ Clin Microbiol 16: 1034-1042.

27. Burke DS, Nisalak A, Ussery MA, Laorakpongse T, Chantavibul $\mathrm{S}, 1985$. Kinetics of IgM and IgG responses to Japanese encephalitis virus in human serum and cerebrospinal fluid. $J$ Infect Dis 151: 1093-1099.

28. Mason PW, 1989. Maturation of Japanese encephalitis virus glycoproteins produced by infected mammalian and mosquito cells. Virology 169: 354-364.

29. Igarashi A, 1978. Isolation of a Singh's Aedes albopictus cell clone sensitive to dengue and chikungunya viruses. J Gen Virol 40: 531-544.

30. Mason PW, McAda PC, Dalrymple JM, Fournier MJ, Mason TL, 1987. Expression of Japanese encephalitis virus antigens in Escherichia coli. Virology 158: 361-372. 